\title{
The Effect of Processing Load on Semantic and Phonological Working Memory in Mild Cognitive Impairment
}

\author{
Hye-In Tak ${ }^{\mathrm{a}}$, Jee Eun Sung ${ }^{\mathrm{b}}$, Jee Hyang Jeong, Geon Ha Kim ${ }^{\mathrm{c}, \mathrm{d}}$ \\ ${ }^{a}$ Graduate Program in Department of Communication Disorder, Ewha Womans University, Seoul, Korea \\ ${ }^{b}$ Department of Communication Disorders, Ewha Womans University, Seoul, Korea \\ 'Department of Neurology, Ewha Womans University Mokdong Hospital, Ewha Womans University School of Medicine, Seoul, Korea

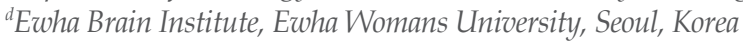

\author{
Correspondence: Jee Eun Sung, PhD \\ Department of Communication Disorders, \\ Ewha Womans University, 52 Ewhayeodae-gil, \\ Seodamun-gu, Seoul 03760, Korea \\ Tel: $+82-2-3277-2208$ \\ Fax: +82-2-3277-2122 \\ E-mail: jeesung@ewha.ac.kr
}

Received: January 12, 2016

Revised: February 13, 2016

Accepted: February 23, 2016

This work was supported by the National Research Foundation of Korea Grant funded by the Korean Government (NRF-2014S1A5A8018080).

\begin{abstract}
Objectives: The current study investigated whether there are differential patterns in verbal working memory (WM) tasks between a normal control group and individuals with mild cognitive impairment (MCl) depending on the manipulation of processing load. Methods: Sixteen individuals with $\mathrm{MCl}$ and 16 normal controls participated in the study. The verbal WM tasks consisted of the two types (semantic vs. phonological). The processing load consisted of two types of manipulations (time-interval vs. interference). In the semantic WM task, participants read the target word and judged, after a certain inter-stimuli interval (ISI), whether following words belong to the same category or not. For the phonological WM condition, participants judged whether the following words rhymed with the target words in a final syllable. Results: Results from time-related processing load (ISI 1s vs. ISI 5s) revealed that the $\mathrm{MCl}$ group showed significantly lower accuracy and longer response time on the WM tasks than the normal group. A significant two-way interaction between the group and WM task types suggested that the $\mathrm{MCl}$ group presented significantly longer response time in the semantic WM task than the phonological WM task compared to the normal group. Results from interference-related processing load (interference vs. no interference) revealed that the $\mathrm{MCl}$ group showed significantly lower accuracy and longer response time than the normal group. Conclusion: The results suggested that the manipulation of the processing load condition showed greater effects on WM task for the MCI group both in accuracy and response time. The study indicates that the type of cognitive processing load may differentially affect different domains ofWM.
\end{abstract}

Keywords: Mild Cognitive Impairment (MCI), Verbal working memory, Working memory tasks, Cognitive processing load
치매의 조기발견의 중요성에 따라 경도인지장애(mild cognitive impairment, MCI)에 대한 관심이 높아지고 있다. 건강보험진료비 지급자료를 분석한 결과에 따르면, $\mathrm{MCI}$ 로 인한 건강보험 진료인원 이 2010년 2만 4천여 명에서 2014년 10만 5천 명으로 약 4.3배 증가 하였다(Ministry of Health and Welfare, 2015). MCI는 정상적인 노화와 dementia of the Alzheimer's type (DAT) 사이에 나타나는 인지장애로 $\mathrm{DAT}$ 의 전이단계이다. $\mathrm{MCI}$ 는 지역사회에서 기억장애
때문에 불편을 겪기는 하지만 독립적인 생활은 잘 유지할 수 있다 (Petersen, 2003). MCI는 크게 기억성 MCI (amnestic MCI)와 비기 억성 MCI (non-amnestic MCI)로 나뉘며(Petersen, 2004), 본 연구 에서는 언어적 작업기억 과제에서 나타나는 기억 손상을 파악하기 위해 기억성 $\mathrm{MCI}$ 를 연구대상으로 선정하였다.

$\mathrm{MCI}$ 의 주요한 증상으로는 일화기억 손상이 지배적이었지만 최 근에는 의미기억 손상 또한 보고되고 있다(Ahmed, Arnold, Thomp- 
son, Graham, \& Hodges, 2008). 기억력 장애가 $\mathrm{MCI}$ 의 특징적인 장 애로 알려져 왔지만 언어능력, 주의집중력 등의 인지기능에도 어느 정도 장애가 동반됨이 알려져 있으며 최근에는 $\mathrm{MCI}$ 의 언어능력에 대한 관심이 증가하고 있다(Kim, Sung, \& Jeong, 2012). 국내 MCI 에 관한 연구를 살펴보면, 경도인지장애의 언어능력에 관한 연구 중 구어유창성과 그림설명하기 과제(Choi, 2011), 이름대기 및 담화 과제(Choi, 2013), 통사적 복잡성에 따른 격조사처리능력(Hyun, Sung, Jeong, Kang, \& Kim, 2013)에서 정상 노인에 비해 수행력이 낮은 결과를 보였다. 그 중 Choi (2011)에 따르면 대면 이름대기 과 제로 검출되지 않았던 기억성 $\mathrm{MCI}$ (amnestic MCI) 환자의 의미적 언어 손상은 담화산출 과제로 검출 가능하며, 이러한 의미적 측면 의 언어수행 능력은 인지기능과 밀접한 관련이 있다고 하였다.

$\mathrm{MCI}$ 와 연관된 인지기능 중 지연회상, 연상학습, 일화기억, 언어 유창성, 주의력에서 정상 노인군과 비교하여 차이가 있다는 연구 보고가 있다(Economou, Papageorgiou, Karageorgiou, \& Vassilopoulos, 2007; Levinoff, Saumier, \& Chertkow, 2005; Nutter-Upham et al., 2008; Petersen et al., 1999). 그리고 MCI와 작업기억(working memory)에 대한 연구에서는 구어적 또는 시각적 작업기억의 손상 을 보고하였다(Montero-Odasso et al., 2009; Saunders \& Summers, 2010). 또한 Gagnon과 Belleville (2011)은 MCI보다 DAT가 작업기 억이 낮고, 정상 노인보다 $\mathrm{MCI}$ 가 작업기억이 낮다는 보고를 하였 다. 사건 관련 전위(event-related potential, ERP), 기능성 자기공명 영상(functional magnetic resonance imaging, fMRI)과 같은 기능 적 영상 데이터를 활용한 연구에서도 작업기억이 $\mathrm{MCI}$ 의 인지적 퇴 행을 예측할 수 있다는 결과(Missonnier et al., 2005)와 DAT로 진 행되는 $\mathrm{MCI}$ 를 예측할 수 있다는 결과(Yetkin, Rosenberg, Weiner, Purdy, \& Cullum, 2006)를 보고하였다.

작업기억은 단순한 저장만을 요구하는 단기기억과 달리 정보의 저장과 처리의 결합이 요구되는 기억체계이다. 이러한 작업기억은 일상생활의 인지활동과 언어이해, 장기학습, 암산을 복합적으로 뒷 받침하는 중요한 역할을 한다(Baddeley \& Hitch, 1974). 정보를 처 리하고 저장할 수 있는 양이 개인마다 다르다는 작업기억용량 이론 (working memory capacity theory)은 Just와 Carpenter (1992)에 의해 연구되었으며, 개인적으로 가지고 있는 작업기억용량에 비해 인지부하가 큰 작업기억 과제를 수행할 때 정보의 소실 또는 처리 의 어려움을 일으킨다. 또한 구어적 작업기억의 중요성을 언급하며 구어적 작업기억용량이 언어이해의 질적 또는 양적으로 차이를 보 인다고 하였다.

작업기억용량을 측정할 수 있는 작업기억 과제로는 단순 폭 과제 (simple memory span task)와 복잡한 과제(complex span task)로
크게 나눌 수 있다. 복잡한 과제는 계산이 포함된 과제로서 단순 폭 과제에 비해작업기억용량을 더 민감하게 측정할수 있다(Unsworth \&Engle, 2007). 또한 n-back 과제는 n번째 전에 제시되었던 자극물 에 대한 질문에 반응을 하도록 구성되어있으며, 인지적 처리 부하 (cognitive processing load)를 다르게 적용할 수 있다. 선행연구에 서는 1-back보다 2-back일 때 인지적 처리 부하가 증가되어 낮은 정 확도나 긴 반응시간을 보인다고 하였다(Wright, Downey, Gravier, Love, \& Shapiro, 2007).

Baddeley와 Hitch (1974)는 작업기억을 처리와 저장 사이를 공유 하는 상호보완적인 자원의 제한된 용량 시스템으로 설명하며, 동 시적으로 인지적 기억 부하가 증가될 때 수행력 저하가 나타난다고 하였다. 저장된 정보의 망각을 유발하는 요인은 크게 시간에 의한 인지적 부하를 설명하는 이론(time-related decay hypotheses)과 간섭에 의한 인지적 부하를 설명하는 이론(interference-based hypotheses)으로 나뉘어 연구되어 왔다(Portrat, Barrouillet, \& Camos, 2008). 시간-관련 감소 이론은 '시간에 근거한 자원-할당'(time-based resource-sharing, TBRS) 모델에 의해 설명할 수 있다. TRBS 모델 은 시간이 지연됨에 따라 주의집중이 사라지고 기억의 흔적 또한 사라진다고 주장한다(Barrouillet, Bernardin, Portrat, Vergauwe, \& Camos, 2007). 그 근거로 작업기억 내에서 이루어지는 정보의 유 지 및 처리와 제한된 주의집중 자원의 관련성을 제시하였다. 즉 주 의집중이 처리하는 데 사용되는 동안, 기억해야 할 목록의 유지가 약해지는 것이다. 주의집중은 새로운 정보를 받아들여 활성화시키 고, 정보의 처리와 유지 사이를 짧은 시간 내 빠르게 전환하며 할당 된다. 또한 TRBS 모델은 주의집중에 필요한 시간의 증가는 인지적 처리 부하가 증가되고 회상하는 수행력도 낮아질 것이라고 예측한 다(Portrat et al., 2008). 이와 관련하여 Gagnon과 Belleville (2011) 은 복잡한 과제인 문장 폭 읽기 과제와 조작 폭 과제에서 단어의 길 이와 제시되는 간격의 길이를 길게 또는 짧게 조작하여 작업기억을 측정하였다. 그 결과, 정상 노년집단에 비해 $\mathrm{MCI}, \mathrm{DAT}$ 가 더 점수가 낮았으며, $\mathrm{MCI}$ 에 비해 DAT가 더 점수가 낮았다. MCI와 DAT 집 단 모두 제시 간격이 길수록 점수가 낮았다. 그러나 단어가 제시되 는 간격의 길이에 더 영향을 받는 집단은 DAT라고 보고하였다. 즉, 유지 간격이 길다는 것은 저장해야 하는 시간이 길어진다는 것을 의미하며, 저장된 정보 유지시간이 늘어날수록 수행력이 낮았다. 이는 시간적 처리부하가 정보의 망각에 민감하게 반응한다는 것을 알수 있다.

반면 Cho, Holyoak 그리고 Cannon (2007)은 처리 과정에서 정 보를 통합하고 방해를 해결해가는 것은 작업기억의 집행기능과 인 지적 조절 능력이 요구된다고 하였다. 따라서 인지적 부담의 증가가 
어떤 처리요소의 결함을 초래하는지 알아보기 위해 시각적 작업기 억 과제를 사용하여 실험하였다. 자극 간 시간을 $1,500 \mathrm{~ms}$ 와 4,500 $\mathrm{ms}$ 로 나누고, 간섭조건을 단계 0 과 1 로 나누어 실험하였다. 간섭조 건 0 단계는 아무런 간섭을 하지 않는 것이고, 단계 1 은 목표와 무 관한 특성을 제시하여 간섭하는 것이다. 그 결과 시간에 따라 수행 력 차이는 없었으며, 간섭조건 1단계에서 더 반응시간이 느렸다. 이 는 시간적인 처리부담보다 목표와 관련 없는 방해물의 간섭이 인지 부담을 증가시켜 작업기억의 처리에 영향을 미쳤다고 할 수 있다.

이처럼 시간 또는 간섭적 요인을 조작한 작업기억, 단기기억 과제 를 MCI대상으로 실시한 결과, 시간적 요인에 의해 수행력이 낮았다 는 결과(Gagnon \& Belleville, 2011)와 간섭적 요인에 의해 수행력 이 낮았다는 결과(Dewar, Pesallaccia, Cowan, Provinciali, \& Della Sala, 2012)가 혼재하다.

또한 언어적 작업기억과제의 국내외 연구 결과를 살펴보면, 국외 연구 중 실어증 환자를 대상으로 언어적 작업기억을 측정한 결과 의미적 정보가 포함된 과제의 수행력이 음운적 정보가 들어간 과 제의 수행력보다 유의하게 높았다(Wright et al., 2007). 또한 Crosson 등(1999)의 연구에서도 음운 작업기억보다 의미 작업기억에서 정확도가 더 높았으며, 빠른 반응시간을 보였다고 하였다. Barde와 Thompson-Schill (2002)은 비단어가 의미단어보다 정확도가 높았 지만 반응시간에 대한 차이는 나타나지 않았다고 하였다. 이처럼 국외에서는 의미 작업기억과제가 음운 작업기억과제에 비해 더 높 은 수행력을 보인다는 결과가 많다. 반면 국내 연구에서는 비단어 회상과제보다 단어나 문장 회상과제가 수행력이 낮다는 결과가 있 다(Kim \& Seo, 2003). 또한 영어권에서는 비단어 따라말하기와 문 장 따라말하기 과제를 통해 말 늦은 아동과 정상 아동을 구분할 수 있다고 하였다. 하지만 국내 연구에서는 비단어 따라말하기는 집단 간 유의한 차이가 없었으며, 문장 따라말하기는 집단 간 유의한 차 이가 있었다. 이는 한국어의 적은 음소 목록과 단순한 음소배열 특 성으로 인해 비단어 따라말하기에서 말 늦은 아동과 정상 아동의 수행력 차이가 나타나지 않았다고 해석할 수 있다(Oh \& Yim, 2013).

본 연구는 $\mathrm{MCI}$ 의 작업기억을 측정하는 단순 폭 과제가 갖는 한 계점을 보완하기 위해, 의미 및 음운 정보가 포함된 작업기억과제 를 제작하여 측정하고자 한다. $\mathrm{MCI}$ 가 정상 노년층에 비해 작업기 억용량이 제한되었을 것이란 예측과 함께 언어적 하위 유형 정보에 따라작업기억과제의 수행력의 차이가 있는지 알아보고자 한다. 그 리고 정보의 망각에 영향을 주는 처리부담을 크게 시간적 처리부 담과 간섭적 처리부담으로 나누어 언어적 작업기억과제에 적용시 켰다. 시간적 처리부담은 먼저 제시된 자극이 종료된 후 그 다음 제 시되는 자극의 출현까지의 시간 간격 즉, 자극 간 간격(inter-stimuli interval, ISI)을 1 초, 5 초로 조작하였다. 그리고 간섭적 처리부담은 간섭자극 유, 무로 조작하였다. 이를 통해 작업기억과제 내에서 어 떠한 처리부담이 정보의 저장 및 처리에 영향을 미치는지 파악할 수 있을 것으로 기대된다.

\section{연구 방법}

\section{연구대상}

본 연구의 대상자는 (1) 서울, 경기 지역에 거주하고, (2) 검사자의 지시를 듣고 과제를 수행하는 데 청력과 시력의 문제가 없으며, (3) 만 60 세 이상인 자로 정상 노인 16명과 MCI 16명, 총 32명을 대상으 로 하였다.

정상 노인은 노인복지관을 통해 참여자를 모집하여 검사를 실시 하였으며, 해당 조건은 다음과 같다. (1) K-MMSE (Korean-Mini Mental State Examination; Kang, Na, \& Hahn, 1997)을 실시하여 정상범위에 해당하는 자, (2) SNSB (Seoul Neuropsychological Screening Battery; Kang \& Na, 2003)의 하위 검사에서 연령 및 교육연수 에 비하여 16\%ile 이상, (3) GDS (Geriatric Depression Scale; Jung et al., 1997)에서 18점 미만이었으며 (4) S-IADL (Seoul-Instrumental Activities of Daily Living; Ku et al., 2004)에서 .43점 미만인 자, (5) 그 외 언어 및 인지적 신경학적 손상이 없는 노인을 대상으로 하 였다. 정상 노인 집단의 SNSB 하위 검사 점수는 Appendix 1 에 제시 하였다.

$\mathrm{MCI}$ 는 대학병원 신경과 전문의로부터 Petersen (2004)의 진단 기준을 사용하여 기억성(amnestic) MCI로 진단된 대상자로 모집 하였다. 세부적인 진단기준은 다음과 같다. (1) 본인이나 보호자에 의한 주관적인 기억장애를 호소한다. (2) 정상 노인과의 비교를 통 한 객관적인 기억장애가 확인된다. (3) 전반적인 인지 기능은 정상 범위에 속한다. (4) 일상생활을 하는 데 어려움을 보이지 않는다. (5) 치매의 기준을 만족시키지 못한다. 또한 (1) CDR (Clinical Dementia Rating; Hughes, Berg, Danziger, Coben, \& Martin, 1982)에서 .5점에 해당하며, (2) S-IADL에서 .43점 미만, (3) GDS에서 18점 미 만이었으며, (4) 대학병원 임상심리사가 실시한 SNSB (Kang \& Na, 2003) 결과를 토대로 연령 및 교육연수에 비하여 언어적 또는 비언 어적 기억력 영역에서 $16 \%$ ile 이하의 프로파일을 보이는 노인을 대 상으로 하였다. MCI 집단의 SNSB 하위 검사 점수는 Appendix 2에 제시하였다.

본 연구에 참여한 집단별 대상자 정보는 Table 1에 제시하였다. 집단 간에 연령, 교육 수준이 통계적으로 유의한 차이가 있는지 알 아보기 위해 일원배치분산분석(one-way ANOVA)을 실시하기 전 
정규분포 및 등분산 가정 검증을 실시하여 모수통계 사용을 위한 가정이 성립되었음을 확인하였다. 이에 따라 일원배치분산분석 (one-way ANOVA)을 실시한 결과, 정상 노인집단과 $\mathrm{MCI}$ 집단 간 연령에 따른 차이가 없었다 $\left(F_{(1,30)}=3.241, p>.05\right)$. 정상 노인집단과 $\mathrm{MCI}$ 집단 간 교육 수준에 따른 차이가 없었다 $\left(F_{(1,30)}=2.227, p>.05\right)$.

Table 1. Descriptive information on participants

\begin{tabular}{lcc}
\hline & $\begin{array}{c}\text { Normal controls group } \\
(\mathrm{N}=16)\end{array}$ & $\begin{array}{c}\text { MCl group } \\
(\mathrm{N}=16)\end{array}$ \\
\hline Gender (male:female) & $4: 12$ & $4: 12$ \\
Age (yr) & $71.44(5.727)$ & $75(5.465)$ \\
Education (yr) & $9(2.191)$ & $7.31(3.985)$ \\
\hline
\end{tabular}

Values are presented as mean (SD) or number.

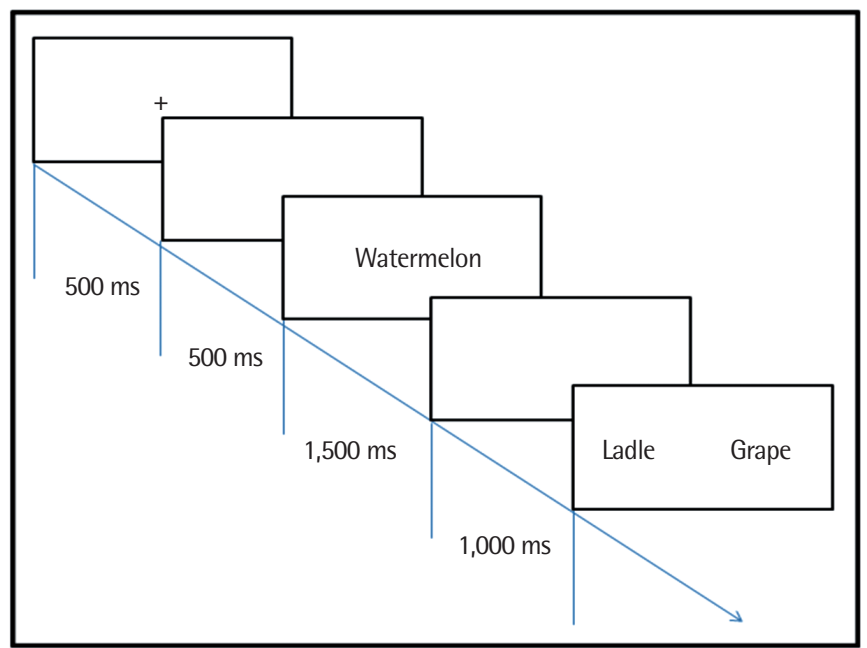

\section{실험 자극}

본 실험 자극은 시간적 처리부담 및 간섭적 처리부담에 따른 언 어적 작업기억과제의 수행력을 살펴보기 위해 자체적으로 제작하 였다. 제작 시 부담 조건을 과제에 반영하기 위해 Temple Assessment of Language and Short-term Memory in Aphasia (TALSA; Tuomiranta, Laine, \& Martin, 2009)에서 제시된 구간 조건(interval condition)을 적용하였다. TALSA (2009)의 3가지 구간 조건을 반영하여 처리부담조건에 따른 언어적 작업기억과제를 제작하였 으며, 처리부담은 아래와 같이 나누었다. 첫째, 시간적 처리부담은 ISI가 1 초인 조건과 5 초인 조건으로 나뉜다. 목표단어가 제시되고 1 초 또는 5 초 후에 화면의 양쪽에 단어 2 개가 나타난다. 즉, 피험자 는 1 초 또는 5 초 후에 판단 과제를 실시하게 된다. 둘째, 간섭적 처리

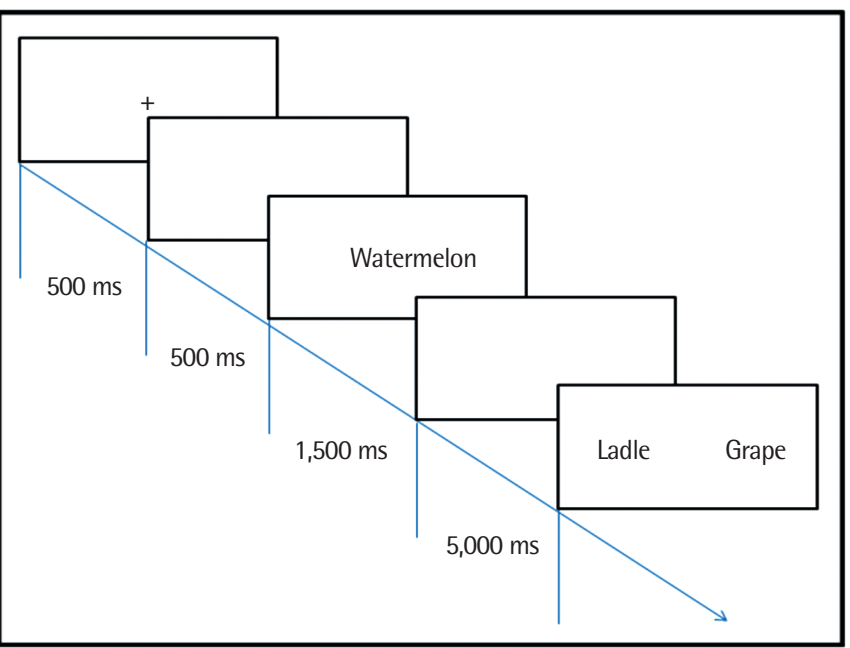

Figure 1. Experimental procedure for time interval manipulation under semantic condition.
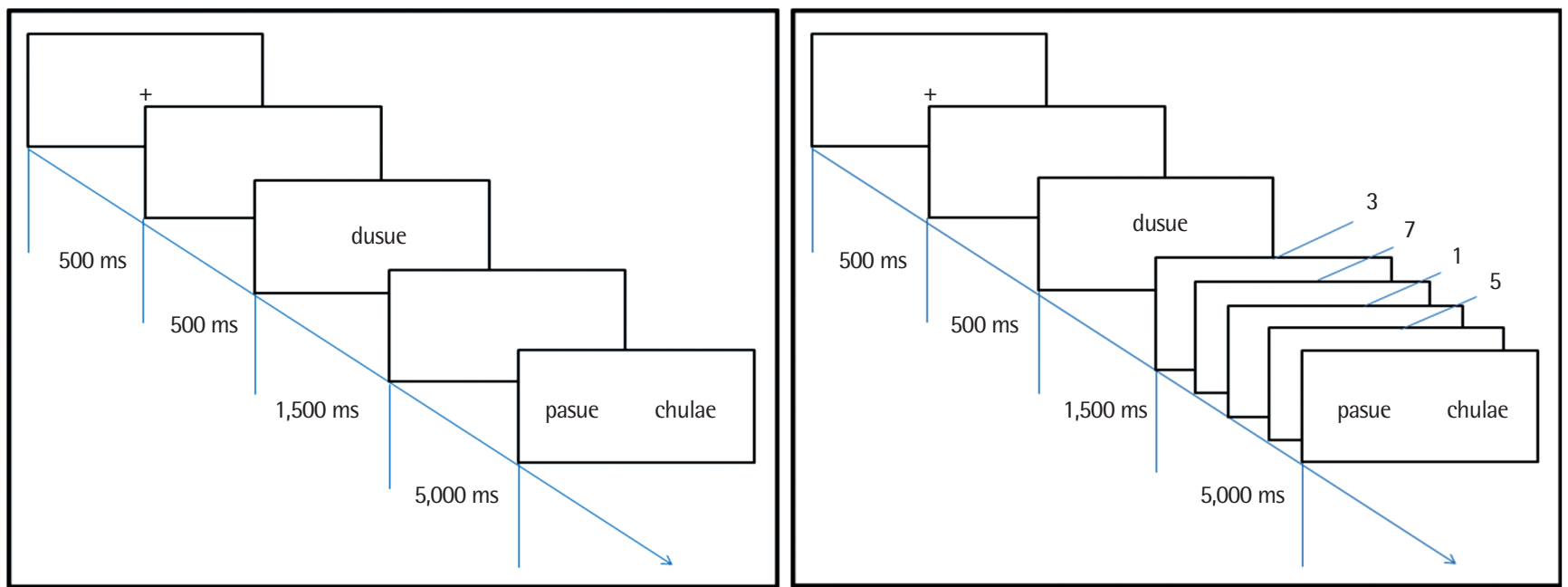

Figure 2. Experimental procedure for interference manipulation under phonological condition. 
Table 2. Examples of experimental categorical words (semantic task)

\begin{tabular}{lccc}
\hline Category & Target word & Same category & Different category \\
\hline Fruits & Banana & Peach & Bowl \\
Animals & Monkey & Donkey & Car \\
Kitchen & Kettle & Chopsticks & Subway \\
Transportation & Truck & Train & Strawberry \\
\hline
\end{tabular}

부담은 일련의 숫자 4 개가 $250 \mathrm{~ms}$ 간격으로 1 개씩 $750 \mathrm{~ms}$ 동안 제 시된다. 일련의 숫자 4 개가 지나가고 숫자를 따라 소리 내어 읽은 뒤, 화면의 양쪽에 단어 2 개가 나타난다. 즉, 피험자는 5 초 동안 숫 자를 소리 내어 읽는 간섭 뒤에 판단 과제를 실시하게 된다. 간섭이 없는 조건에서는 빈 화면이 5 초 동안 제시된 뒤에 판단 과제를 실시 하게 된다. 처리부담 조건에 따른 언어적 작업기억과제는 세부적으 로 의미 작업기억과제와 음운 작업기억과제로 나누어 제작하였다. 실험 순서도는 Figures 1,2 와 같다.

의미 작업기억과제는 목표단어를 기억하고 의미 범주를 판단하 는 과제이다. 범주의 생물성 균형을 맞추고자 의미 범주는 생물 범 주 2가지, 무생물 범주 2가지 총 4가지로 구성하였다. Sung 등(2014) 에서 연구된 노년층의 명사 친숙도 및 산출빈도를 고려하여 범주별 단어를 구성하였다. 생물 범주는 동물과 과일 범주로, 무생물 범주 는 교통수단과주방용품 범주로 선정하였다. 단어는 범주별로 고빈 도 단어 중 12 개를 선정하여 총 48 개로 구성하였다. 실험 자극은 1 세트로 구성하였으며, 처리부담 조건별 과제에 따라 무선적으로 배 열하였다. 실험 자극의 예는 Table 2 와 같다.

음운 작업기억과제는 목표단어를 기억하고 끝음절의 동일성을 판단하는 과제이다. 단어의 의미를 배제하기 위해 비단어로 구성하 였으며, 제시되는 비단어의 음운 형태는 CVCV, CVCVC, CVCCV, $\operatorname{CVCCVC~(C,~ㅈㅏㅇㅡㅁ;~} \mathrm{V}$, 모음)로 모두 2음절로 구성하였다. 비단어는 Lee와 Kim (2006)의 비단어 읽기과제에서 사용된 비단어를 수정, 보완하여 사용하였다. 4 가지 음운형태별로 6 개씩 각각 목표단어 24 개, 끝음절이 같은 단어 24 개, 끝음절이 다른 단어 24 개로 총 72 개를 구성하였다. 실험 자극은 1 세트로 구성하였으며, 처리부담 조 건별 과제에 따라 무선적으로 배열하였다. 실험 자극의 예는 Table 3과 같다.

\section{연구도구}

모니터 해상도가 $1,920 \times 1,080$ 의 13 인치 모니터 노트북(LG$\mathrm{Z} 360)$ 에 이프라임(E-Prime 2.0)을 장착하여 실험을 진행하였다. 바 탕화면은 흰색이고 모든 단어는 검정색 글자로 설정하였으며 글씨 체는 맑은 고딕, 크기는 44 point로 설정하였다. '오른쪽' 버튼은 '”
Table 3. Examples of experimental non-words (phonological task)

\begin{tabular}{lccc}
\hline Phonological type & Target word & Same category & Different category \\
\hline CVCV & dusue & pasue & chulae \\
CVCVC & kugyun & jagyun & gidad \\
CVCCV & dungyu & jubgyu & dangui \\
CVCCVC & chapbin & gyunbin & lukgal \\
\hline
\end{tabular}

$\mathrm{C}=$ consonant; $\mathrm{V}=$ vowel.

키로 설정하고 ‘오’라고 표기된 흰색 종이를 붙였고, ‘왼쪽'버튼은 'Z'키로 설정하고 '왼'이라고 표기된 흰색 종이를 붙여 표시하였다. 대상자에게 버튼 선택에 있어 혼란을 주지 않기 위해 해당 버튼 이 외의 모든 키보드 판은 가렸다.

\section{연구 절차}

실험은 서울 및 경기 지역의 노인복지관과 치매지원센터에서 이 루어졌으며 조용하고 독립된 공간에서 연구자와 일대일로 진행되 었다. 인지적 처리부하가 낮은 조건부터 진행하기 위해 ISI가 1 초인 조건, ISI가 5초인 조건, 간섭이 있는 조건 순으로 실시하였다. 처리 부담 조건별 과제 사이에는 자동적으로 프로그램이 중단되고 휴 식을 가진 뒤에 진행하였다. 역균형화를 위해서, 집단별로 8 명에게 는 의미 작업기억과제를 먼저 실시하였고, 나머지 8 명에게는 음운 작업기억과제를 먼저 실시하였다.

조건별 과제 내에서 각 문항은 응시점(+)이 $500 \mathrm{~ms}$ 동안 제시되 면서 시작된다. 응시점(+)이 사라지고 이어서 흰색 빈 화면이 500 $\mathrm{ms}$ 동안 제시된 후 목표단어가 $1,500 \mathrm{~ms}$ 동안 제시된다. 목표단어 가 나타났다가 사라지고 처리부담 조건에 따라 화면이 제시된다. ISI가 1 초인 조건 과제에서는 $1,000 \mathrm{~ms}$ 동안의 빈 화면이 나타나고, ISI가 5 초인 조건 과제에서는 $5,000 \mathrm{~ms}$ 동안의 빈 화면이 나타난다. 간섭이 있는 조건 과제에서는 일련의 숫자 4 개가 $250 \mathrm{~ms}$ 간격으로 하나씩 $750 \mathrm{~ms}$ 동안 나타나면 숫자를 따라서 소리 내어 읽도록 하 였다. 처리부담 조건별로 설정된 화면이 사라지고 두 개의 단어가 화면의 오른쪽과 왼쪽에 동시에 나타난다. 이때, 의미 작업기억과 제는 두 개의 단어 중 '앞서 나타난 단어와 의미적 범주 즉, 같은 종 류의 단어'라고 생각되는 쪽의 버튼을 누르도록 지시하였다. 오른 쪽에 나타난 단어가 앞서 나타난 단어와 의미적 범주가 같다면 '오 른쪽' 버튼을, 왼쪽에 나타난 단어가 앞서 나타난 단어와 의미적 범 주가 같다면 '왼쪽' 버튼을 누르도록 지시하였다. 반면 음운 작업기 억과제는 처리부담 조건별로 설정된 화면이 사라지고 두 개의 단어 가 화면의 오른쪽과 왼쪽에 동시에 나타나면, 두 개의 단어 중 '앞 서 나타난 단어와 끝음절이 같은 단어'라고 생각되는 쪽의 버튼을 누르도록 지시하였다. 설명이 끝나면 연습문항을 본 과제 전에 제 
시하였다. 연습문항은 처리부담 조건별 과제에 따라 3 문항씩 구성 하였다. 연습문항을 실시하면서 연구자는 대상자가 과제 수행 방법 을 이해할 수 있도록 하였다. 연구자는 대상자의 반응에 ‘맞았습니 다', '틀렸습니다' 문구를 반응속도와 함께 화면에 제시하여 피드백 을 주었다. 대상자가 과제에 대해 이해할 수 있도록 설명한 뒤에 본 과제를 실시하였다

\section{자료 분석}

\section{정확도(accuracy)}

대상자가 같은 범주단어 또는 같은 끝음절 단어를 선택한 경우 만을 정반응으로 처리하여 분석한다. 정반응은 1 점, 다른 범주단어 또는 다른 끝음절 단어를 선택한 경우 오반응으로 처리하여 0 점으 로 계산한다. 정반응한 문항 수를 각 과제별 총 문항 수인 24로 나 눈 후 100 을 곱하여 정확도(\%)를 계산하였다.

\section{반응시간(response time)}

목표단어가 제시된 뒤 화면의 ‘오른쪽'과 ‘왼쪽'에 두 개의 단어가 제시되었을 때, 같은 의미범주 또는 같은 끝음절을 판단한 후 '오른 쪽' 또는 '왼쪽'버튼을 누른 시간까지를 측정한다. 이는 E-prime을 통해 자동적으로 밀리세컨드 $(\mathrm{ms})$ 단위로 측정된다. 처리부담 조건 이 적용된 각 과제별로 대상자가 정반응한 반응시간의 평균(소수 점 이하 2자리)과 표준편차(standard deviation, $\mathrm{SD}$ )를 계산하였다. 그 중 $3 \mathrm{SD}$ 이상 되는 반응시간은 이상값(outlier)으로 처리하여 제 외하였다. 그리고 집단별로 전체 대상자 반응시간의 평균과 $\mathrm{SD}$ 를 계산하고 $3 \mathrm{SD}$ 이상 되는 반응시간은 이상값(outlier)으로 처리하 여 제외하였다(DeDe, Caplan, Kemtes, \& Waters, 2004).

\section{자료의 통계적 처리}

시간적 처리부담 조건과 언어적 작업기억과제 유형에 따라 집단 간 정확도 및 반응시간에 유의미한 차이가 있는지 알아보기 위해 삼원혼합분산분석(three-way mixed ANOVA)을 실시하였다. 집 단을 집단 간 요인으로, 시간적 처리부담과 언어적 작업기억과제 유 형을 집단 내 요인으로 한 $3 \times 3$ 삼원혼합분산분석을 두 가지 종속 변수(정확도 및 반응시간)에 관해 각각 실시하였다. 또한 간섭적 처 리부담 조건과 언어적 작업기억과제 유형에 따라 집단 간 정확도 및 반응시간에 유의미한차이가 있는지 알아보기 위해 삼원혼합분 산분석(three-way mixed ANOVA)을 실시하였다. 집단을 집단 간 요인으로, 간섭적 처리부담과 언어적 작업기억과제 유형을 집단 내 요인으로 한 $3 \times 3$ 삼원혼합분산분석을 두 가지 종속변수(정확도 및 반응시간)에 관해 각각 실시하였다. 분석은 SPSS ver. 20 (IBM,
Armonk, NY, USA)을 사용하였다. 정규분포 및 구형성 가정 검증 을 실시하여 모수통계 사용 가설검증이 충족됨을 확인하였으며, 단 구형성 가정이 충족되지 않았을 경우 Greenhouse-Geiser의 F 및 $p$-value를 보고하였다.

\section{연구 결과}

\section{시간적 처리부담 및 과제 유형에 따른 집단 간 작업기억과제 정확도 분석 결과}

정상 노인과 $\mathrm{MCI}$ 의 시간적 처리부담 및 과제 유형에 따른 작업 기억과제 정확도는 Figure 3 과 같다.

의미 작업기억과제에서 ISI 1 초인 경우, 정상 노인집단은 $97.65 \%$, $\mathrm{MCI}$ 집단은 $83.07 \%$ 의 정확도를 보였다. 또한 ISI 5 초인 경우, 정상 노인집단은 $97.39 \%, \mathrm{MCI}$ 집단은 $86.46 \%$ 의 정확도를 보였다. 음운 작업기억과제에서 ISI 1 초인 경우, 정상 노인집단은 $99.22 \%, \mathrm{MCI}$ 집 단은 $96.61 \%$ 의 정확도를 보였다. 또한 ISI 5 초인 경우, 정상 노인집 단은 $98.96 \%, \mathrm{MCI}$ 집단은 $94 \%$ 의 정확도를 보였다. 작업기억과제 정확도(\%)를 종속변수로 한 삼원혼합분산분석 결과, 집단에 대한 주효과는 통계적으로 유의하였다. 즉, $\mathrm{MCI}$ 집단의 정확도가 정상노 인집단에 비해 유의하게 낮았다 $\left(F_{(1,30)}=7.653, p<.05\right)$. 또한 과제 유 형에 대한 주효과가 통계적으로 유의하였다. 즉, 의미 작업기억과제 가 음운 작업기억과제에 비해 정확도가 유의하게 낮았다 $\left(F_{(1,30)}=\right.$ $11.112, p<.005)$. 하지만 시간적 처리부담에 대한 주효과는 통계적 으로 유의하지 않았다 $\left(F_{(1,30)}=.003, p>.05\right)$. 작업기억과제 정확도에 서, 과제 유형과 집단에 대한 이차상호작용이 통계적으로 유의하였 다 $\left(F_{(1,30)}=6.115, p<.05\right)$. 이차상호작용이 나타난 것은, 두 집단 모 두 음운 작업기억과제에 비해 의미 작업기억과제의 정확도가 낮았 지만 그 차이가 $\mathrm{MCI}$ 집단에서 더 크게 나타났기 때문이다. 하지만 시간적 처리부담과 집단에 대한 이차상호작용 $\left(F_{(1,30)}=.082, p>.05\right)$

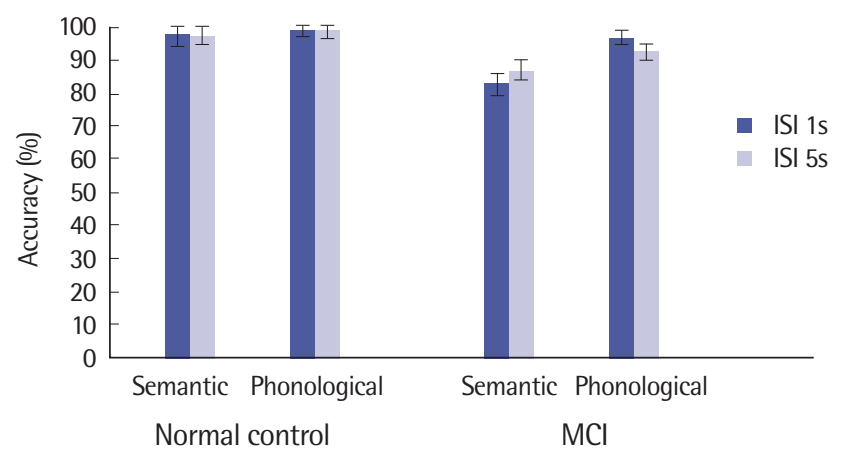

Figure 3. Accuracy on time interval manipulation for each group and condition. $\mathrm{MCl}=$ mild cognitive impairment; $|\mathrm{S}|$ = inter stimuli interval. 
과, 시간적 처리부담과 과제 유형에 대한 이차상호작용은 통계적으 로 유의하지 않았다 $\left(F_{(1,30)}=1.823, p>\right.$.05). 또한 시간적 처리부담 및 과제 유형에 따른 집단 간 차이에 관한 삼차상호작용이 통계적으 로 유의하지 않았다 $\left(F_{(1,30)}=1.822, p>.05\right)$.

\section{시간적 처리부담 및 과제 유형에 따른 집단 간 작업기억과제 반응시간 분석 결과}

집단 내 반응시간 평균을 기준으로 $3 \mathrm{SD}$ 이상의 값, 즉 이상값 (oulier)을 보인 MCI 1명을 제외하고 MCI 15명, 정상 노인 16명을 분석하였다. 정상 노인과 $\mathrm{MCI}$ 의 시간적 처리부담 및 과제 유형에 따른 작업기억과제 반응시간은 Figure 4 와 같다. 의미 작업기억과 제에서 ISI 1 초인 경우, 정상 노인집단은 $1,235 \mathrm{~ms}, \mathrm{MCI}$ 집단은 2,396 $\mathrm{ms}$ 의 반응시간을 보였다. 또한 ISI 5 초인 경우, 정상 노인집단은 $1,278 \mathrm{~ms}, \mathrm{MCI}$ 집단은 $3,017 \mathrm{~ms}$ 의 반응시간을 보였다. 음운 작업기 억과제에서 ISI 1초인 경우, 정상 노인집단은 $884 \mathrm{~ms}, \mathrm{MCI}$ 집단은 $1,175 \mathrm{~ms}$ 의 반응시간을 보였다. 또한 ISI 5 초인 경우, 정상 노인집단 은 $934 \mathrm{~ms}, \mathrm{MCI}$ 집단은 $1,792 \mathrm{~ms}$ 의 반응시간을 보였다. 작업기억과 제 반응시간 $(\mathrm{ms})$ 를 종속변수로 한 삼원혼합분산분석 결과, 집단 에 대한 주효과가 통계적으로 유의하였다. 즉, $\mathrm{MCI}$ 집단의 반응시 간이 정상 노인집단에 비해 느렸다 $\left(F_{(1,29)}=22.777, p<.001\right)$. 또한 과 제 유형에 대한 주효과가 통계적으로 유의하였다 $\left(F_{(1,29)}=42.489\right.$, $p<.001)$. 즉, 의미 작업기억과제가 음운 작업기억과제에 비해 반응 시간이 느렸다. 더불어 시간적 처리부담에 대한 주효과가 통계적으 로 유의하였다. 즉, ISI 1초인 조건에 비해 ISI 5초인 조건에서 반응 시간이 느렸다 $\left(F_{(1,29)}=27.129, p<.001\right)$ 작업기억과제 반응시간에 서, 과제 유형과 집단에 대한 이차상호작용이 통계적으로 유의하였 다 $\left(F_{(1,29)}=13.202, p<.01\right)$. 상호작용이 나타난 것은, 두 집단 모두 음운 작업기억과제보다 의미 작업기억과제에서 반응시간이 느렸 지만 그 차이가 $\mathrm{MCI}$ 집단에서 더 크게 나타났기 때문이다. 또한 시

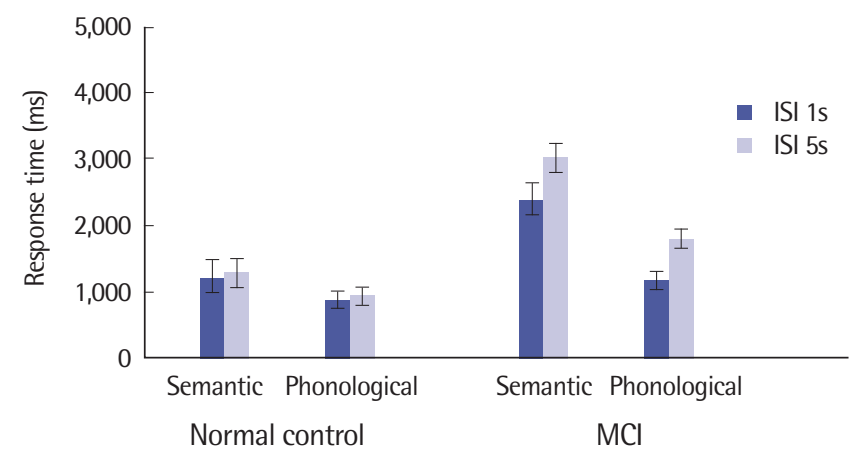

Figure 4. Response time on time interval manipulation for each group and condition. $\mathrm{MCl}=$ mild cognitive impairment; $\mid \mathrm{SI}=$ inter stimuli interval.
간적 처리부담과 집단에 대한 이차상호작용이 통계적으로 유의하 였다 $\left(F_{(1,29)}=20.137, p<.001\right)$. 상호작용이 나타난 것은, 두 집단 모 두 ISI 1 초인 조건에 비해 ISI 5 초인 조건에서 반응시간이 느렸지만 그 차이가 $\mathrm{MCI}$ 집단에서 더 크게 나타났기 때문이다. 반면 과제 유 형과 시간적 처리부담에 대한 이차상호작용이 통계적으로 유의하 지 않았으며 $\left(F_{(1,29)}=.000, p>.05\right)$, 과제 유형 및 시간적 처리부담과 집단에 대한 삼차상호작용이 통계적으로 유의하지 않았다 $\left(F_{(1,29)}=\right.$ $.003, p>.05)$.

\section{간섭적 처리부담 및 과제 유형에 따른 집단 간 작업기억과제 정확도 분석 결과}

정상 노인과 $\mathrm{MCI}$ 의 시간적 처리부담 및 과제 유형에 따른 작업 기억과제 정확도는 Figure 5 와 같다. 의미 작업기억과제에서 간섭 이 있는 경우, 정상 노인집단은 $93.48 \%, \mathrm{MCI}$ 집단은 $79.42 \%$ 의 정확 도를 보였다. 또한 간섭이 없는 경우, 정상 노인집단은 $97.39 \%, \mathrm{MCI}$ 집단은 $86.45 \%$ 의 정확도를 보였다. 음운 작업기억과제에서 간섭이 있는 경우, 정상 노인집단은 $98.17 \%, \mathrm{MCI}$ 집단은 $84.37 \%$ 의 정확도 를 보였다. 또한 간섭이 없는 경우, 정상 노인집단은 $98.95 \%, \mathrm{MCI}$ 집 단은 $94 \%$ 의 정확도를 보였다. 작업기억과제 정확도(\%)를 종속변수 로 한 삼원혼합분산분석 결과, 집단에 대한 주효과는 통계적으로 유의하였다. 즉, $\mathrm{MCI}$ 집단의 정확도가 정상 노인집단에 비해 유의 하게 낮았다 $\left(F_{(1,30)}=11.560, p<.01\right)$. 또한 과제 유형에 대한 주효과 가 통계적으로 유의하였다. 즉, 의미 작업기억 과제가 음운 작업기 억과제에 비해 정확도가 유의하게 낮았다 $\left(F_{(1,30)}=15.585, p<.001\right)$. 또한 간섭적 처리부담에 대한 주효과가 통계적으로 유의하였다. 즉, 간섭이 있는 경우가 간섭이 없는 경우에 비해 정확도가 유의하 게 낮았다 $\left(F_{(1,30)}=21.907, p<.001\right)$. 작업기억과제 정확도에서, 과제 유형과 집단에 대한 이차상호작용 $\left(F_{(1,30)}=1.731, p>.05\right)$, 과제 유형 과간섭적 처리부담에 대한 이차상호작용 $\left(F_{(1,30)}=.015, p>.05\right)$ 이 통

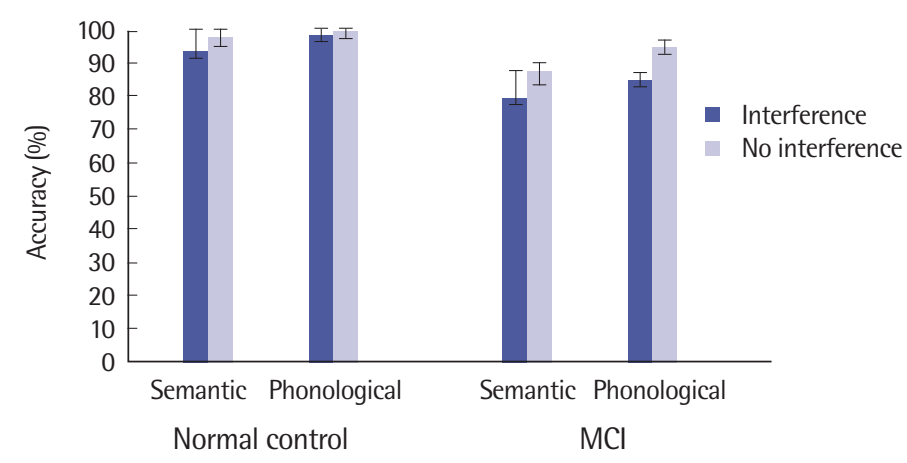

Figure 5. Accuracy on interference manipulation for each group and condition. $\mathrm{MCl}=$ mild cognitive impairment. 


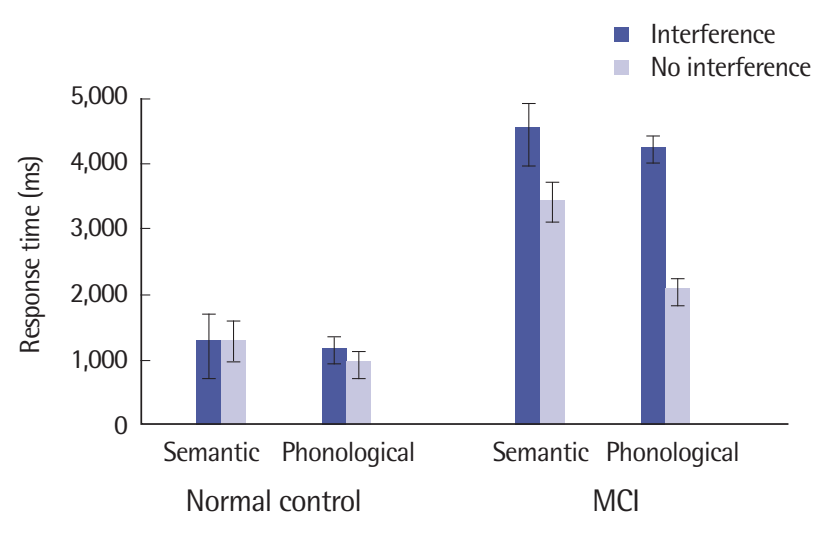

Figure 6. Response time on interference manipulation for each group and condition. $\mathrm{MCl}=$ mild cognitive impairment.

계적으로 유의하지 않았다. 또한 과제 유형 및 간섭적 처리부담과 집단에 대한 삼차상호작용이 통계적으로 유의하지 않았다 $\left(F_{(1,30)}=\right.$ $1.854, p>.05)$. 반면 간섭적 처리부담과 집단에 대한 이차상호작용 이 통계적으로 유의하였다 $\left(F_{(1,30)}=6.895, p<.05\right)$. 상호작용이 나타 난 것은, 두 집단 모두 간섭이 있는 경우가 없는 경우에 비해 정확도 가 낮았지만 그 차이가 $\mathrm{MCI}$ 집단에서 더 크게 나타났기 때문이다.

\section{간섭적 처리부담 및 과제 유형에 따른 집단 간 작업기억과제 반응시간 분석 결과}

정상 노인과 $\mathrm{MCI}$ 의 시간적 처리부담 및 과제 유형에 따른 작업 기억과제 반응시간은 Figure 6과 같다. 의미 작업기억과제에서 간 섭이 있는 경우, 정상 노인집단은 $1,307 \mathrm{~ms}, \mathrm{MCI}$ 집단은 $4,548 \mathrm{~ms}$ 의 반응시간을 보였다. 또한 간섭이 없는 경우, 정상 노인집단은 1,278 $\mathrm{ms}, \mathrm{MCI}$ 집단은 $3,400 \mathrm{~ms}$ 의 반응시간을 보였다. 음운 작업기억과 제에서 간섭이 있는 경우, 정상 노인집단은 $1,172 \mathrm{~ms}, \mathrm{MCI}$ 집단은 $4,248 \mathrm{~ms}$ 의 반응시간을 보였다. 또한 간섭이 없는 경우, 정상 노인 집단은 $934 \mathrm{~ms}, \mathrm{MCI}$ 집단은 $2,063 \mathrm{~ms}$ 반응시간을 보였다. 작업기억 과제 반응시간 $(\mathrm{ms})$ 을 종속변수로 한 삼원혼합분산분석 결과, 집 단에 대한 주효과는 통계적으로 유의하였다. 즉, $\mathrm{MCI}$ 집단의 반응 시간이 정상 노인집단에 비해 느렸다 $\left(F_{(1,30)}=23.668, p<.001\right)$. 또한 과제 유형에 대한 주효과가 통계적으로 유의하였다. 즉, 의미 작업 기억과제가 음운 작업기억과제에 비해 반응시간이 느렸다 $\left(F_{(1,30)}=\right.$ $5.601, p<.05)$. 또한 간섭적 처리부담에 대한 주효과가 통계적으로 유의하였다. 즉, 간섭이 있는 경우가 간섭이 없는 경우에 비해 반응 시간이 느렸다 $\left(F_{(1,30)}=22.853, p<.001\right)$. 작업기억과제 반응시간에 서, 과제 유형과 집단에 대한 이차상호작용 $\left(F_{(1,30)}=1.674, p>.05\right)$, 과제 유형과 간섭적 처리부담에 대한 이차상호작용 $\left(F_{(1,30)}=3.656\right.$, $p>$.05)이 통계적으로 유의하지 않았다. 또한 과제 유형 및 간섭적
처리부담과 집단에 대한 삼차상호작용이 통계적으로 유의하지 않 았다 $\left(F_{(1,30)}=1.615, p>.05\right)$. 반면 간섭적 처리부담과 집단에 대한 이 차상호작용이 통계적으로 유의하였다 $\left(F_{(1,30)}=16.561, p<.005\right)$. 상 호작용이 나타난 것은, 두 집단 모두 간섭이 있는 경우가 없는 경우 에 비해 반응시간이 느렸지만 그 차이가 $\mathrm{MCI}$ 집단에서 더 크게 나 타났기 때문이다.

\section{논의 및 결론}

본 연구에서는 언어적 작업기억과제에 처리부담 조건을 적용하 여 정상 노인과 $\mathrm{MCI}$ 의 수행력을 비교하고자 하였다. 언어적 작업기 억과제는 의미적 정보를 바탕으로 한 의미 작업기억과제, 음운적 정보를 바탕으로 한 음운 작업기억과제로 나누었다. 또한 정보의 망각이 시간에 의한 것인지, 간섭에 의한 것인지 알아보고자 (1) 시 간적 처리부담(ISI 1초, ISI 5초) (2) 간섭적 처리부담(간섭 유, 간섭 무)을 언어적 작업기억과제에 적용시켰다. 즉, 정상 노인과 $\mathrm{MCI}$ 를 대상으로 처리부담 조건 및 과제 유형에 따른 언어적 작업기억과제 정확도와 반응시간을 분석하여 두 집단에서 어떠한 차이를 보이는 지 알아보기 위해 실시되었다.

시간적 처리부담 및 언어적 작업기억 과제 유형에 따른 작업기억 과제 정확도 분석 결과, $\mathrm{MCI}$ 집단의 정확도가 정상 노인집단에 비 해 유의하게 낮은 것으로 나타났다. 이 결과는 $\mathrm{MCI}$ 가 작업기억 과 제에서 정상집단에 비해 수행력이 낮다는 많은 선행연구와 일치한 다(Belleville, Chertkow, \& Gauthier, 2007; Engle \& Kane, 2004; Gagnon \& Belleville, 2011; Saunders \& Summers, 2011). 이는 국내 선행연구 결과와도 일치한다(Kim, Park, \& Lee, 2007). 정보를 저 장하고 유지하여 처리하는 작업기억 과제는 작업기억 용량이 중요 한 역할을 하는데, 제한된 작업기억 용량은 과제의 수행력 저하를 불러일으킨다. 때문에 작업기억 용량이 부족하면 정보를 기억하고 과제를 처리하는 것이 적절하게 공유되지 못한다(Just \& Carpenter, 1992). 즉, MCI가 제한된 작업기억 용량으로 인해 의미 및 음운 적 정보를 저장하고 유사성에 따라 단어를 판단하여 처리하는 것 에 어려움이 있었다고 해석할 수 있다. 또한 과제 유형에 따른 주효 과가 유의하여, 의미 작업기억과제 조건에 비해 음운 작업기억과제 에서 정확도가 높았다. 이는 의미적 정보를 저장하고 처리하는 것 보다 음운적 정보를 저장하고 처리하는 것에 대한 수행력이 높았다 고 할 수 있다. 이러한 결과는 정상 성인을 대상으로 한 의미 정보 및 음운 정보가 포함된 언어적 작업기억과제 연구 결과와 일치하지 않았다. 즉, 음운적 정보보다 의미적 정보를 저장하고 처리하는 과 제의 수행력이 높았다는 국외 연구 결과와도 일치하지 않았다(Barde 
\& Thompson-Schill, 2002; Crosson et al., 1999). 이러한 불일치는 비단어 어휘판단과제를 사용하여 한국어 시각 단어 재인과정에 대한 연구 결과로 설명할 수 있다. 한국어의 경우 시각 단어 재인과 정에서 음운 정보는 부수적인 역할을 하며, 표기 정보가 주로 사용 된다(Tae, Lee, \& Lee, 2015). 의미적 또는 음운적 단서를 주어 단어 유창성 과제를 실시하여 국외 연구와 다른지 알아본 결과, 국외에 서는 의미적 단어 생성의 수행이 더 좋았지만 한국어 연구에서는 음운적 단어 생성의 수행이 유의미하게 높았다(Lee \& Lee, 2000). 이러한 의미적, 음운적 처리에 관한 국내외 연구의 불일치는 한글 과 영어의 다른 특성으로 설명할 수 있다. 한글과 영어는 같은 음소 문자이지만 한글은 영어와 다르게 자음자와 모음자가 별개의 바탕 에서 제작되어 뚜렷하게 구별되고, 음절단위로 조합하여 배열하기 때문이다(Yoon \& Kwon, 1995). 본 연구에서 음절의 유사성을 토대 로 음운적 유사성을 판단하게 하였기 때문에 음운 정보보다 표기 정보로 기억하여 처리했을 가능성이 크다. 이로 인해 의미적 정보 보다 음운적 정보를 더 정확하게 저장하고 처리하여 음운 작업기 억과제의 정확도가 높았던 것으로 해석할 수 있다. 마지막으로 과 제 유형과 집단에 대한 이차상호작용이 통계적으로 유의하였다. 이 는 두 집단 모두 의미 작업기억과제에 비해 음운 작업기억과제에서 정확도가 높았지만 그 차이가 $\mathrm{MCI}$ 집단에서 더 크게 나타났기 때 문이다. 즉, $\mathrm{MCI}$ 집단이 정상 집단에 비해 의미 작업기억과제의 수 행력이 더 낮았다. 이러한 결과는 MCI집단이 초기 DAT와 유사한 의미적 측면의 두드러진 손상이 있으며, 음운이나 구문적 측면에 서는 비교적 유지가 되고 있다는 측면에서 설명할 수 있다(Taler \& Phillips, 2008). MCI의 의미적 측면에서 보이는 언어 손상 국내 연 구를 살펴보면, 대면이름대기 및 산출적 측면에서의 담화능력은 정상 노년층과 비교하여 차이가 없었다. 하지만 문장수준과 의미적 측면에서의 담화능력은 정상 노년층과 $\mathrm{MCI}$ 의 차이가 있는 결과를 보였다. 이는 의미적 언어 손상이 단순한 의미체계상의 손상에 기 인한 것이 아닌 신경병리적 특성에 기인한 것이라고 볼 수 있다. 또 한 DAT의 전이단계가 $\mathrm{MCI}$ 라는 점에서 신경병리적 특성 또한 연 장선상에 있으며, DAT가 보이는 해마의 위축 및 용적 감소가 $\mathrm{MCI}$ 에서도 나타난다는 점에서 초기 DAT와 유사한 의미적 측면의 두 드러진 손상을 보인다고 할 수 있다(Choi, Kim, Lee, \& Kim, 2013).

시간적 처리부담 및 과제 유형에 따른 반응시간 분석 결과, $\mathrm{MCI}$ 집단의 반응시간이 정상집단에 비해 유의하게 느린 것으로 나타났 다. 또한 시간적 처리부담에 따른 주효과가 유의하여, ISI 1 초 조건 보다 ISI 5초 조건에서 반응시간이 유의하게 느렸다. 이러한 결과는 Portrat 등(2008)의 주장과 일치한다. 이들은 작업기억 용량은 시간 이 지연됨에 따라 주의집중이 저하되고 기억의 흔적이 감소한다고
주장하였다. 즉, 기억의 흔적이 유지되려면 주의집중이 새로운 정 보를 받아들여 활성화시키고, 정보의 유지와 처리 사이를 전환하 며 할당해야 한다. 하지만 ISI 1 초 조건보다 ISI 5 초 조건에서 정보 의 유지와 처리가 원활하게 전환하지 못하여 반응시간이 느려졌다 고 할 수 있다. 또한 정보를 유지하는 시간이 1초 조건으로 짧을 때 보다 5 초 조건으로 지연되었을 때, 기억의 흔적이 감소하여 반응시 간에 부정적인 영향을 미쳤다고 해석할 수 있다. 또한 시간적 처리 부담과 집단에 대한 이차상호작용이 통계적으로 유의하였다. 이는 두 집단 모두 ISI 1초 조건에 비해 ISI 5초 조건에서 반응시간이 느렸 지만 그차이가 $\mathrm{MCI}$ 집단에서 더 크게 나타났기 때문이다. 즉, $\mathrm{MCI}$ 집단이 정상 집단에 비해 ISI 5 초 조건에서 반응시간이 더 느렸다. 작업기억은 동시적으로 인지적 기억 부하가 증가될 때 수행력 저하 가 나타나며, 처리의 어려움이 증가되면 단기기억 내 저장소의 정보 를 잃는다고 하였다(Baddeley \& Hitch, 1974). 즉, 시간적 처리부담 이 인지적 기억 부하를 증가시키고 처리의 어려움을 불러일으켜 $\mathrm{MCI}$ 의 언어적 작업기억과제의 반응시간 상승에 기여했다고 해석 할 수 있다. 앞서 정확도에서는 이차상호작용이 나타나지 않았지만 반응시간에서는 시간적 처리부담에 따라 집단 간 차이를 보였다. 이는 fMRI를 활용하여 작업기억과제의 수행력을 측정한 연구(Honey, Bullmore, \& Sharma, 2000)에 따르면, 뇌의 기능적인 측면과 상 관관계를 보이는 것은 정확도가 아닌 반응시간이라고 하였다. 즉, 반응시간이 과제의 수행력을 더 영향력 있게 예측할 수 있는 요소 이다. 따라서 시간적 처리부담에 따른 집단 간 차이가 정확도보다 반응시간에서 더 민감하게 반영되었음을 알 수 있다. 마지막으로 과제 유형과 집단에 대한 이차상호작용이 통계적으로 유의하였다. 이는 두 집단 모두 음운 작업기억과제에 비해 의미 작업기억과제에 서 반응시간이 느렸지만, 그 차이가 $\mathrm{MCI}$ 집단에서 더 크게 나타났 기 때문이다. 즉, $\mathrm{MCI}$ 집단이 정상 집단에 비해 의미 작업기억과제 의 반응시간이 더 느렸다.

간섭적 처리부담 및 언어적 작업기억과제 유형에 따른 작업기억 과제 정확도 분석 결과, $\mathrm{MCI}$ 집단의 정확도가 정상집단에 비해 유 의하게 낮은 것으로 나타났다. 또한 과제 유형에 따른 주효과가 유 의하여, 음운적 작업기억과제보다 의미적 작업기억과제에서 정확 도가 유의하게 낮은 것으로 나타났다. 또한 간섭적 처리부담 조건 에 따른 주효과가 유의하여, 불필요한 정보가 없는 조건보다 불필 요한 정보가 있는 조건에서 정확도가 유의하게 낮은 것으로 나타났 다. 이는 간섭에 근거한 이론(interference-based hypotheses)으로 설명할 수 있다. 간섭의 조건은 여러 연구에서 기억의 망각이 기억 해야 할 목록들의 중첩, 특성의 중복, 인출단서의 혼란으로 인해 일 어난다고 주장하였다(Lewandowsky, Oberauer, \& Brown, 2009). 
다른 간섭의 조건으로는 과제수행과 관계 없는 불필요한 방해 요인 을 들 수 있다(Cho et al., 2007; Crowder, 1972). 또한 간섭의 위치에 따라 순행 및 역행 간섭으로 나누었다. 이에 본 연구에서는 불필요 한 방해 요인으로 일련의 숫자를 소리 내어 말하도록 하였고, 기억 해야 할 정보 뒤에 위치시켜 역행 간섭을 하였다. 숫자를 소리 내어 말하는 외현적 조음 활동이 암묵적으로 단어를 되새기는 것을 저 지(rehearsal-blocking)하여 불필요한 방해를 했다고 볼 수 있다 (Dewar et al., 2012). 즉, 과제를 수행하는 데 불필요한 간섭이 목표 단어의 망각을 불러일으키고 작업기억과제의 정확도에 영향을 주 었다고 해석할 수 있다. 마지막으로 간섭적 처리부담 조건과 집단 에 대한 이차상호작용이 통계적으로 유의하였다. 이는 두 집단 모 두 불필요한 정보가 없는 조건에 비해 불필요한 정보가 있는 조건 에서 정확도가 낮았지만 그 차이가 $\mathrm{MCI}$ 집단에서 더 크게 나타났 기 때문이다. 즉, $\mathrm{MCI}$ 집단이 정상 집단에 비해 불필요한 정보가 있 는 조건에서 수행력이 더 낮았다. 이러한 결과는 $\mathrm{MCI}$ 집단이 정상 노년층에 비해 민감하게 간섭을 받는다는 선행연구와 일치한다 (Cowan, Beschin, Perini, \& Della Sala, 2005; Dewar et al., 2012). 선 행연구들의 경우 지연 회상과제를 사용하여 단순한 정보 저장과 인출이라는 단기기억 내에서 불필요한 간섭을 주었다. 단기기억에 서 비롯된 작업기억도 간섭에 영향을 받는다고 할 수 있으며, 정상 노년층은 간섭을 억제하고 정확하게 과제를 수행하는 반면, $\mathrm{MCI}$ 는 간섭이 처리부담을 증가시키고 기억 흔적을 감소시켜 언어적 작 업기억과제의 수행력이 낮았다고 해석할 수 있다.

간섭적 처리부담 및 과제 유형에 따른 반응시간 분석 결과, $\mathrm{MCI}$ 집단의 반응시간이 정상집단에 비해 유의하게 느린 것으로 나타났 다. 또한 과제 유형에 따른 주효과가 유의하여, 음운적 작업기억과 제보다 의미적 작업기억과제에서 반응시간이 유의하게 느린 것으 로 나타났다. 또한 간섭적 처리부담 조건에 따른 주효과가 유의하 여, 간섭이 없는 조건보다 간섭이 있는 조건에서 반응시간이 유의 하게 느린 것으로 나타났다. 반응시간은 fMRI, Positron Emission Tomography (PET)와 같은 뇌기능영상 신호와 상관관계를 보이며 구어적 작업기억에 있어 중요한 측정 자료로 사용되고 있다. 또한 $n$-back 과제를 활용하여 인지적 처리부하를 증가시킬 경우, 반응시 간이 느려진다는 보고가 있다(Honey et al., 2000; Jonides et al., 1997). 이를 본 연구에 적용시켜 본다면, 간섭이 없는 조건보다간섭 이 있는 조건에서 인지적 처리부하가 증가되었다고 해석되며 그에 따라 반응시간이 느려졌다고 할 수 있다. 또한 간섭적 처리부담과 집단에 대한 이차상호작용이 통계적으로 유의하였다. 이는 두 집 단 모두 간섭이 없는 조건에 비해 간섭이 있는 조건에서 반응시간 이 느렸지만 그 차이가 $\mathrm{MCI}$ 집단에서 더 크게 나타났기 때문이다.
즉, $\mathrm{MCI}$ 집단이 정상 집단에 비해 간섭이 있는 조건에서 반응시간 이 더 느렸다. 이러한 결과는 MCI집단이 정상 노년층에 비해 민감 하게 간섭을 받는다는 선행연구와 일치한다(Cowan et al., 2005; Dewar et al., 2012). 이러한 선행연구들은 단기기억에 간섭을 주고 회상률을 측정하고 반응시간에 대한 결과가 없다는 제한점이 있 다. 앞서 말한 듯, 반응시간이 구어적 작업기억의 중요한 측도로 사 용되는 만큼 $\mathrm{MCI}$ 의 간섭적 조건에 따른 언어적 작업기억 과제 반 응시간은 중요한 의미를 갖는다. 반면, 집단과 과제 유형에 대한 이 차상호작용은 나타나지 않았다. 이는 시간적 처리부담이 적용된 언어적 작업기억과제에서는 과제 유형과 집단에 대한 이차상호작 용이 나타났다는 점과 비교하여 해석할 수 있다. 즉 시간적 처리부 담에서는 과제 유형에 따라 집단 간 차이가 있었지만, 간섭적 처리 부담에서는 과제 유형에 따른 집단 간 차이가 없었다. 이는 간섭적 처리부담 자체가 이미 인지적 처리 부하를 높여 $\mathrm{MCI}$ 와 정상 노년 층을 구분하였기 때문이다. 따라서 과제 유형이 영향을 미치지 못 하였고 과제 유형에 따른 집단 간차이가 나타나지 않았다.

본 연구 결과를 종합해보면 정상 노년층과 $\mathrm{MCI}$ 가 언어적 작업기 억과제 수행력 차이를 보였으며, $\mathrm{MCI}$ 가 더 낮은 정확도와 느린 반 응시간을 보였다. 정보의 저장과 처리과정에서 어려움을 주는 요인 은 시간적 처리부담과 간섭적 처리부담 모두 영향을 미쳤다고 할 수 있으며, $\mathrm{MCI}$ 가 정상 노년층에 비해 처리부담에 더 민감하게 반 응한다는 것을 알 수 있었다. 또한 시간적 처리부담에서는 작업기 억과제 유형에 따라 $\mathrm{MCI}$ 와 정상 노년층의 차이가 있어, $\mathrm{MCI}$ 가 의 미적 정보의 저장과 처리에 어려움이 있다는 것을 알 수 있었다. 하 지만 간섭적 처리부담에서는 작업기억과제 유형에 따른 집단 간 차 이가 나타나지 않았다. 즉 간섭이 있는 조건에서 이미 인지적 처리 부하를 높여 과제 유형에 관계없이 낮은 수행력과 느린 반응시간을 보였다. 따라서 시간적 요소가 $\mathrm{MCI}$ 의 언어적 하위 유형에 따른 정 보 망각을 확인할 수 있는 민감한 요소라고 할 수 있다. 반면, 간섭 적 요소는 간섭 자체가 $\mathrm{MCI}$ 와 정상 노년층을 구분하는 민감한 요 소라고 할 수 있다. 이러한 연구 결과는 향후 연구목적에 따라 처리 부담 요인을 조작하여 $\mathrm{MCI}$ 와 정상 노인의 차이가 나타나는 영역 을 확인하는 데 도움이 될 것으로 기대된다. 하지만 본 연구는 $\mathrm{MCI}$ 16 명과 정상 노년층 16 명으로 대상자의 수가 제한되어 있어 연구의 결과를 일반화하는 데 한계가 있다. 또한 다영역 기억성(multiple domain) MCI만을 대상자로 선정했다는 제한점이 있다. 추후 연구 에서는 충분한 수의 대상자를 모집하여 기억성 $\mathrm{MCI}$ 를 단일 영역 (single domain) 기억성 MCI와 다영역(multiple domain) 기억성 $\mathrm{MCI}$ 로 나누어 비교하는 연구가 필요할 것이다. 


\section{REFERENCES}

Ahmed, S., Arnold, R., Thompson, S. A., Graham, K. S., \& Hodges, J. R. (2008). Naming of objects, faces and buildings in mild cognitive impairment. Cortex, 44, 746-752.

Baddeley, A. D., \& Hitch, G. (1974). Working memory. Psychology of Learning And Motivation, 8, 47-89.

Barde, L. H., \& Thompson-Schill, S. L. (2002). Models of functional organization of the lateral prefrontal cortex in verbal working memory: evidence in favor of the process model. Journal of Cognitive Neuroscience, 14, 10541063.

Barrouillet, P., Bernardin, S., Portrat, S., Vergauwe, E., \& Camos, V. (2007). Time and cognitive load in working memory. Journal of Experimental Psychology: Learning, Memory, and Cognition, 33, 570-585.

Belleville, S., Chertkow, H., \& Gauthier, S. (2007). Working memory and control of attention in persons with Alzheimer's disease and mild cognitive impairment. Neuropsychology, 21, 458-469.

Cho, S., Holyoak, K. J., \& Cannon, T. D. (2007). Analogical reasoning in working memory: resources shared among relational integration, interference resolution, and maintenance. Memory \& Cognition, 35, 1445-1455.

Choi, H. (2011). Detecting language deficits in patients with mild cognitive impairment through verbal fluency and picture description tasks. Korean Journal of Communication Disorders, 16, 171-184.

Choi, H. (2013). Characteristics of naming and discourse in patients with amnestic mild cognitive impairment. Journal of Speech-Language \& Hearing disorders, 22, 17-33.

Choi, H., Kim, J. H., Lee, C. M., \& Kim, J. I. (2013). Features of semantic language impairment in patients with amnestic mild cognitive impairment. Dementia and Neurocognitive Disorders, 12, 33-40.

Cowan, N., Beschin, N., Perini, M., \& Della Sala, S. (2005). Just lying there, remembering: Improving recall of prose in amnesic patients with mild cognitive impairment by minimising interference. Memory, 13, 435-440.

Crosson, B., Rao, S. M., Woodley, S. J., Rosen, A. C., Bobholz, J. A., Mayer, A., ... \& Cox, R. W. (1999). Mapping of semantic, phonological, and orthographic verbal working memory in normal adults with functional magnetic resonance imaging. Neuropsychology, 13, 171-187.

Crowder, R. G. (1972). Visual and auditory memory. In J. F. Kavanagh \& I. G. Mattingly (Eds.), Language by ear and by eye; the relationships between speech and reading (pp. 251-275). Cambridge, MA: MIT Press.

DeDe, G., Caplan, D., Kemtes, K., \& Waters, G. (2004). The relationship be- tween age, verbal working memory, and language comprehension. Psychology and Aging, 19, 601-616.

Dewar, M., Pesallaccia, M., Cowan, N., Provinciali, L., \& Della Sala, S. (2012). Insights into spared memory capacity in amnestic MCI and Alzheimer's disease via minimal interference. Brain and Cognition, 78, 189-199.

Economou, A., Papageorgiou, S. G., Karageorgiou, C., \& Vassilopoulos, D. (2007). Nonepisodic memory deficits in amnestic MCI. Cognitive and Behavioral Neurology, 20, 99-106.

Engle, R. W., \& Kane, M. J. (2004). Executive attention, working memory capacity, and a two-factor theory of cognitive control. Psychology of Learning and Motivation, 44, 145-200.

Gagnon, L. G., \& Belleville, S. (2011). Working memory in mild cognitive impairment and Alzheimer's disease: contribution of forgetting and predictive value of complex span tasks. Neuropsychology, 25, 226-236.

Honey, G. D., Bullmore, E. T., \& Sharma, T. (2000). Prolonged reaction time to a verbal working memory task predicts increased power of posterior parietal cortical activation. NeuroImage, 12, 495-503.

Hughes, C. P., Berg, L., Danziger, W. L., Coben, L. A., \& Martin, R. (1982). A new clinical scale for the staging of dementia. British Journal of Psychiatry, $140,566-572$.

Hyun, J. M., Sung, J. E., Jeong, J. H., Kang, H. J., \& Kim, H. J. (2013). Effects of syntactic complexity on a case marker processing task in people with mild cognitive impairment. Communication Sciences \& Disorders, 18, 3546.

Jonides, J., Schumacher, E. H., Smith, E., Lauber, E. J., Awh, E., Minoshima, S., ... \& Koeppe, R. (1997). Verbal working memory load affects regional brain activation as measured by PET. Journal of Cognitive Neuroscience, 9 , 462-475.

Jung, I. K., Kwak, D. I., Shin, D. K., Lee, M. S., Lee, H. S., \& Kim, J. Y. (1997). A reliability and validity study of geriatric depression scale. Journal of Korean Neuropsychiatric Association, 36, 103-112.

Just, M. A., \& Carpenter, P. A. (1992). A capacity theory of comprehension: individual differences in working memory. Psychological Review, 99, 122149.

Kang, Y. W., Chin, J. H., Na, D. L., Lee, J. H., \& Park, J. S. (2000). A normative study of the Korean version of Controlled Oral Word Association Test (COWAT) in the elderly. Korean Journal of Clinical Psychology, 19, 385-392.

Kang, Y., \& Na, D. L. (2003). Seoul Neuropsychological Screening Battery. Incheon: Human Brain Research \& Consulting Co.

Kang, Y., Na, D. L., \& Hahn, S. (1997). A validity study on the Korean Mini- 
Mental State Examination (K-MMSE) in dementia patients. Journal of the Korean Neurological Association, 15, 300-308.

Kim, H., Park, J. K., \& Lee, K. J. (2007). The neurocognitive function of mild cognitive impairment: a comparison of patients with Alzheimer's disease and normal controls. Journal of Rehabilitation Psychology, 14, 1-16.

Kim, J. K., Sung, J. E., \& Jeong, J. H. (2012). Effects of syntactic complexity on sentence comprehension in persons with mild cognitive impairment and dementia of Alzheimer's type. Korean Journal of Communication Disorders, $17,338-355$.

Kim, M., K., \& Seo, G., H. (2003). A study of phonological processing ability in children with reading disabilities. Journal of Special Education: Theory and Practice, 4, 241-258.

Ku, H. M., Kim, J. H., Kwon, E. J., Kim, S. H., Lee, H. S., Ko, H. J., ... \& Kim, D. K. (2004). A study on the reliability and validity of Seoul-Instrumental Activities of Daily Living (S-IADL). Journal of Korean Neuropsychiatric Association, 43, 189-199.

Lee, J. H., Kang, Y. W., \& Na, D. L. (2000). Efficiencies of Stroop interference indexes in healthy older adults and dementia patients. Korean Journal of Clinical Psychology, 19, 807-818.

Lee, J. Y., \& Kim, J. M. (2006). Effect of combined word recognition and reading comprehension intervention on reading pseudowords for school-aged children with reading disabilities. Korean Journal of Communication Disorders, $11,64-81$.

Lee, S. H., \& Lee, K. M. (2000). Brain activation associated with word fluency tasks: a functional magnetic resonance image study. Journal of the Korean Neurological Association, 18, 138-143.

Levinoff, E. J., Saumier, D., \& Chertkow, H. (2005). Focused attention deficits in patients with Alzheimer's disease and mild cognitive impairment. Brain and Cognition, 57, 127-130.

Lewandowsky, S., Oberauer, K., \& Brown, G. D. (2009). No temporal decay in verbal short-term memory. Trends in Cognitive Sciences, 13, 120-126.

Ministry of Health and Welfare. (2015). Mild cognitive impairment before the dementia. Sejong, Korea: Author.

Missonnier, P., Gold, G., Fazio-Costa, L., Michel, J. P., Mulligan, R., Michon, A., ... \& Giannakopoulos, P. (2005). Early event-related potential changes during working memory activation predict rapid decline in mild cognitive impairment. Journals of Gerontology Series A: Biological Sciences and Medical Sciences, 60, 660-666.

Montero-Odasso, M., Bergman, H., Phillips, N. A., Wong, C. H., Sourial, N., \& Chertkow, H. (2009). Dual-tasking and gait in people with mild cogni- tive impairment: the effect of working memory. BMC Geriatrics, 9, 41.

Nutter-Upham, K. E., Saykin, A. J., Rabin, L. A., Roth, R. M., Wishart, H. A., Pare, N., ... \& Flashman, L. A. (2008). Verbal fluency performance in amnestic MCI and older adults with cognitive complaints. Archives of Clinical Neuropsychology, 23, 229-241.

Oh, D. Y., \& Yim, D. (2013). Non-word repetition and sentence repetition performance in 2-3 years old late talkers and normal children. Communication Sciences \& Disorders, 18, 277-287.

Petersen, R. C. (2003). Conceptual overview. In R. C. Petersen (Ed.), Mild cognitive impairment: aging to Alzheimer's disease (pp. 1-14). Oxford: Oxford University Press.

Petersen, R. C. (2004). Mild cognitive impairment as a diagnostic entity. Journal of Internal Medicine, 256, 183-194.

Petersen, R. C., Smith, G. E., Waring, S. C., Ivnik, R. J., Tangalos, E. G., \& Kokmen, E. (1999). Mild cognitive impairment: clinical characterization and outcome. Archives of Neurology, 56, 303-308.

Portrat, S., Barrouillet, P., \& Camos, V. (2008). Time-related decay or interference-based forgetting in working memory? Journal of Experimental Psychology: Learning, Memory, and Cognition, 34, 1561-1564.

Saunders, N. L., \& Summers, M. J. (2010). Attention and working memory deficits in mild cognitive impairment. Journal of Clinical and Experimental Neuropsychology, 32, 350-357.

Saunders, N. L., \& Summers, M. J. (2011). Longitudinal deficits to attention, executive, and working memory in subtypes of mild cognitive impairment. Neuropsychology, 25, 237-248.

Sung, J. E., Mo, K. O., Lee, J. S., \& Sim, H. S. (2014). Production frequency, semantic typicality, and familiarity of noun exemplars for elderly adults. Communication Sciences \& Disorders, 19, 213-225.

Tae, J., Lee, C., \& Lee, Y. (2015). The effect of the orthographic and phonological priming in Korean visual word recognition. Korean Journal of Cognitive Science, 26, 1-26.

Taler, V., \& Phillips, N. A. (2008). Language performance in Alzheimer's disease and mild cognitive impairment: a comparative review. Journal of Clinical and Experimental Neuropsychology, 30, 501-556.

Tuomiranta, L., Laine, M., \& Martin, N. (2009). Adaptation of the temple assessment of language and short-term memory in aphasia (TALSA) into the Finnish language. Unpublished manuscript.

Unsworth, N., \& Engle, R. W. (2007). On the division of short-term and working memory: an examination of simple and complex span and their relation to higher order abilities. Psychological Bulletin, 133, 1038-1066. 
Wright, H. H., Downey, R. A., Gravier, M., Love, T., \& Shapiro, L. P. (2007). Processing distinct linguistic information types in working memory in aphasia. Aphasiology, 21, 802-813.

Yetkin, F. Z., Rosenberg, R. N., Weiner, M. F., Purdy, P. D., \& Cullum, C. M. (2006). FMRI of working memory in patients with mild cognitive impairment and probable Alzheimer's disease. European Radiology, 16, 193-206.

Yim, D. (2013). Non-word repetition and sentence repetition performance in
2-3 years old late talkers and normal children. Communication Sciences \& Disorders, 18, 277-287.

Yoon, H. K., \& Kwon, O. S. (1995). Phoneme recognition ability and reading strategy in hangil acquisition stage child. Proceedings of the Korean Psychological Association Annual Conference, 1, 233-240.

Yum, T. H., Park, Y. S., Oh, K. J., Kim, J. K., \& Lee, Y. H. (1992). Korean Wechsler Adult Intelligence Scale (K-WAIS). Seoul: Guidance Korea. 
Appendix 1. 정상 노인의 SNSB 하위 검사 점수(\%ile)

\begin{tabular}{|c|c|c|c|c|c|c|c|}
\hline \multirow{2}{*}{ 대상자 영역 } & \multirow{2}{*}{$\begin{array}{c}\text { 집중력 } \\
\text { Digit span1) }\end{array}$} & \multirow{2}{*}{$\begin{array}{l}\text { 언어능력 } \\
\text { S-K-BNT²) }\end{array}$} & \multirow{2}{*}{$\frac{\text { 시공간 능력 }}{\mathrm{RCFT}^{3)}}$} & \multicolumn{2}{|c|}{ 기억력 } & \multicolumn{2}{|c|}{ 전두엽/집행기능 } \\
\hline & & & & $\mathrm{SVLT}^{4)}$ & $\mathrm{RCFT}^{5)}$ & COWAT $^{6)}$ & $\mathrm{K}-\mathrm{CWST}^{7)}$ \\
\hline 1 & 49.87 & 78.81 & 84.61 & 29.46 & 42.07 & 70.19 & 99.32 \\
\hline 2 & 52.39 & 67.72 & 93.19 & 82.89 & 99.99 & 98.50 & 95.73 \\
\hline 3 & 22.66 & 87.29 & 75.54 & 79.10 & 79.95 & 79.30 & 88.3 \\
\hline 4 & 72.24 & 86.21 & 90.49 & 95.00 & 98.50 & 99.60 & 99.94 \\
\hline 5 & 89.25 & 92.65 & 75.80 & 77.34 & 47.61 & 96.68 & 92.36 \\
\hline 6 & 34.46 & 99.64 & 91.77 & 59.48 & 45.55 & 99.11 & 94.10 \\
\hline 7 & 81.06 & 83.65 & 65.17 & 70.19 & 26.11 & 60.64 & 97.72 \\
\hline 8 & 17.35 & 62.93 & 90.49 & 95.99 & 95.45 & 22.66 & 90.87 \\
\hline 9 & 50.00 & 84.61 & 73.89 & 66.64 & 79.67 & 89.80 & 85.99 \\
\hline 10 & 78.81 & 65.17 & 85.31 & 82.38 & 99.34 & 99.85 & 89.44 \\
\hline 11 & 67.00 & 80.78 & 84.13 & 89.25 & 62.93 & 75.49 & 87.49 \\
\hline 12 & 79.39 & 96.71 & 87.71 & 62.55 & 20.61 & 89.80 & 85.99 \\
\hline 13 & 64.06 & 35.94 & 37.83 & 30.85 & 32.64 & 58.32 & 95.25 \\
\hline 14 & 50.00 & 95.05 & 92.79 & 92.22 & 32.64 & 76.11 & 89.44 \\
\hline 15 & 48.40 & 68.71 & 75.51 & 50.80 & 50.40 & 30.50 & 59.48 \\
\hline 16 & 38.97 & 81.59 & 98.17 & 70.19 & 82.12 & 85.31 & 87.29 \\
\hline
\end{tabular}

1) Digit span=한국판 웩슬러 지능검사 숫자외우기(Yum, Park, Oh, Kim, \& Lee, 1992)

2) S-K-BNT=Short version of the Korean-Boston Naming Test - form A (Kim \& Na, 1997).

3) RCFT=Rey Complex Figure Test-copyscore (Meyers\& Meyers, 1995).

4) SVLT=Seoul Verbal Learning Test-delayed recall (Kang \& Na, 2003).

5) RCFT-delayed recall.

6) COWAT=Controlled Oral Word Association Test (Kang, Chin, Na, Lee, \& Park, 2000).

7) K-CWST=Korean-Color Word Stroop Test (Lee, Kang, \& Na, 2000)를 이용함.

Appendix 2. MCI의 SNSB 하위 검사 점수(\%ile)

\begin{tabular}{|c|c|c|c|c|c|c|c|}
\hline \multirow{2}{*}{ 대상자 영역 } & \multirow{2}{*}{$\begin{array}{c}\text { 집중력 } \\
\text { Digit span1) }\end{array}$} & \multirow{2}{*}{$\begin{array}{l}\text { 언어능력 } \\
\text { K-BNT2) }\end{array}$} & \multirow{2}{*}{$\begin{array}{c}\text { 시공간 능력 } \\
\text { RCFT' }^{3)}\end{array}$} & \multicolumn{2}{|c|}{ 기억력 } & \multicolumn{2}{|c|}{ 전두엽/집행기능 } \\
\hline & & & & $\mathrm{SVLT}^{4)}$ & $\mathrm{RCF}^{5)}$ & COWAT $^{6)}$ & $\mathrm{K}-\mathrm{CWST}^{7}$ \\
\hline 1 & 42.07 & 48.01 & 6.18 & 1.22 & 2.68 & 1.16 & 2.94 \\
\hline 2 & 5.16 & 63.31 & 84.13 & 12.92 & 13.79 & 16.11 & .01 \\
\hline 3 & 17.36 & .01 & 57.14 & 12.92 & 97.50 & 2.39 & 17.11 \\
\hline 4 & 22.36 & 5.16 & 93.19 & 38.21 & 13.90 & 27.43 & 68.44 \\
\hline 5 & 2.33 & 2.62 & 71.57 & 25.78 & 9.01 & 69.50 & 98.08 \\
\hline 6 & 3.92 & 40.52 & 76.67 & 40.13 & .39 & 9.01 & 12.51 \\
\hline 7 & 48.40 & 2.94 & 84.61 & 50.80 & 2.39 & 52.79 & 44.43 \\
\hline 8 & 2.33 & 41.29 & .15 & 39.36 & 9.01 & 44.04 & 50.40 \\
\hline 9 & 15.87 & .01 & 43.25 & 29.46 & 6.43 & 78.23 & 66.64 \\
\hline 10 & 6.18 & 10.38 & .22 & 50.80 & 2.39 & 25.46 & 42.86 \\
\hline 11 & 2.28 & 65.17 & 85.08 & 94.95 & 10.38 & 85.77 & 89.07 \\
\hline 12 & 50.00 & .80 & 59.10 & 3.51 & 28.77 & 16.85 & 85.08 \\
\hline 13 & 21.48 & 17.36 & 8.08 & 50.80 & .87 & 58.32 & 41.29 \\
\hline 14 & 34.46 & 70.19 & .01 & 9.68 & .04 & 18.67 & 50.40 \\
\hline 15 & 21.48 & 37.83 & .02 & 50.80 & 3.75 & 69.15 & 83.89 \\
\hline 16 & 50.00 & 15.62 & 84.61 & 3.51 & 6.43 & 61.03 & 53.59 \\
\hline
\end{tabular}

1) Digit span=한국판 웩슬러 지능검사 숫자외우기(Yum, Park, Oh, Kim, \& Lee, 1992).

2) S-K-BNT=Short version of the Korean-Boston Naming Test-form A (Kim \& Na, 1997).

3) RCFT=Rey Complex Figure Test-copyscore (Meyers \& Meyers, 1995).

4) SVLT=Seoul Verbal Learning Test-delayed recall (Kang \& Na, 2003).

5) RCFT-delayed recall.

6) COWAT=Controlled Oral Word Association Test (Kang, Chin, Na, Lee, \& Park, 2000).

7) K-CWST=Korean-Color Word Stroop Test (Lee, Kang, \& Na, 2000)를 이용함. 


\section{국문초록}

\section{경도인지장애군에서 처리부담조건이 의미 및 음운 작업기억에 미치는 영향}

탁혜인 ${ }^{1} \cdot$ 성지은 ${ }^{2} \cdot$ 정지향 3 김건하 ${ }^{3,4}$

${ }^{1}$ 이화여자대학교 대학원 언어병리학과, ${ }^{2}$ 이화여자대학교 언어병리학과, ${ }^{3}$ 이화여자대학교 목동병원 신경과, ${ }^{4}$ 이화뇌융합과학연구원

배경 및 목적: 처리부담조건 및 언어적 작업기억과제 유형이 작업기억과제 수행에 어떠한 영향을 미치는지 경도인지장애(MCI)와 정상 노인을 대상으로 살펴보고자 한다. 방법: 정상 노인 16 명과 $\mathrm{MCI} 16$ 명 총 32 명을 대상으로 하였다. 처리부담조건을 시간적 처리부담과 간섭적 처리부담으로 반영하여 언어적 작업기억과제를 제작하였다. 시간적 처리부담은 자극 간 간격(ISI)를 1 초 vs. 5 초로 조작하였으 며, 간섭적 처리부담은 간섭자극의 유 vs. 무로 조작하였다. 대상자가 화면에 제시된 목표단어를 보고 목표단어와 같은 의미범주 또는 끝음절 단어를 판단하여 선택함으로써 정확도와 반응시간을 측정하여 분석하였다. 결과: 시간적 처리부담이 반영된 작업기억과제에 서 MCI가 정상 노인에 비해 ISI -1초인 조건보다 ISI -5초인 조건에서 낮은 정확도와 느린 반응시간을 보였으며, $\mathrm{MCI}$ 가 정상 노인에 비 해 음운 작업기억과제보다 의미 작업기억과제에서 느린 반응시간을 보였다. 간섭적 처리부담이 반영된 작업기억과제에서 $\mathrm{MCI}$ 가 정상 노인에 비해 간섭이 없는 조건보다 간섭이 있는 조건에서 낮은 정확도와 느린 반응시간을 보였다. 하지만 의미, 음운과제 유형에 따른 집 단 간 차이는 나타나지 않았다. 논의 및 결론: 시간적 요소가 MCI의 언어 하위 유형에 따른 정보 망각을 확인할 수 있는 민감한 요소인 반면, 간섭적 요소는 언어 하위 유형보다 MCI와 정상 노인집단 자체를 구분하는 요소라고 할 수 있다.

핵심어: 경도인지장애, 언어적 작업기억, 작업기억과제, 처리부담

본 연구는 2014년도 정부재원으로 한국연구재단의 지원에 의한 연구임.

\section{참고문헌}

강연욱, 나덕렬(2003). 서울신경심리검사(Seoul Neuropsychological Screening Battery). 인천: 휴브알엔씨.

강연욱, 나덕렬, 한승혜(1997). 치매 환자들을 대상으로 한 K-MMSE의 타당도연구. 대한신경과학회지, 15, 300-308.

강연욱, 진주희, 나덕렬, 이정희, 박재설(2000). 통제 단어 연상 검사 (Controlled Oral Word Association Test)의 노인 규준 연구. 한국심리학회지: 임 상, 19, 385-392.

구형모, 김지혜, 권의정, 김성환, 이형석, 고혜정, 안상미, 김도관(2004). 일상활동평가-복합(Seoul-Instrumental Activities of Daily Living; S-IADL)의 신뢰도 및 타당도 연구. 대한신경정신의학회지, 43, 189-199.

김미경, 서경희(2003). 읽기장애 아동의 음운처리 능력 특성 연구. 특수교육저널: 이론과 실천, 4, 241-258.

김향희, 나덕렬(1997). 한국판 보스톤이름대기검사(Korean-Boston Naming Test; K-BNT). 서울: 학지사.

김현, 박중규, 이강준(2007). 경도인지장애의 신경인지기능: 알쯔하이머병 환자와 정상대조군과의 비교. 재활심리연구, 14, 1-16. 보건복지부(2015). 치매로 가기 전 경도인지장애. 세종: 보건복지부.

염태호, 박영숙, 오경자, 김정규, 이영호(1992). 한국판 Wechsler 성인용 지능 검사(K-WAIS): 실시 요강. 서울: 한국가이던스.

윤혜경, 권오식(1995). 한글터득 단계 아동의 음운인식능력과 읽기책략 한국심리학회 학술발표논문집, 1,233-240.

이수화, 이경민 (2000). 단어 유창성 검사수행에 동반된 뇌활성화양상: 기능적 자기공 명영상 연구. 대한신경과학회지, 18, 138-143.

이정희, 강연욱, 나덕렬(2000). Stroop 간섭 지표들의 효율성 비교. 한국심리학회지: 임상, 19, 807-818.

이지영, 김정미(2006). 단어재인과 읽기이해의 혼합 중재가 초등학교 읽기장애 아동의 비단어읽기에 미치는 효과. 언어청각장애연구, $11,64-81$.

정인과, 곽동일, 신동균, 이민수, 이현수, 김진영(1997). 노인우울척도(Geriatric Depression Scale)의 신뢰도, 타당도 연구. 신경정신의학, 36, 103-112.

최현주(2011). 구어유창성과 그림설명과제를 통한 경도인지 장애(MCI) 환자의 언어손상 검출. 언어청각장애연구, 16, 171-184.

최현주(2013). 건망형 경도인지장애 환자의 이름대기 및 담화 과제의 수행 특성. 언어치료연구, 22, 17-33.

최현주, 김지현, 이창민, 김재일(2013). 기억형 경도인지장애 환자의 의미적 측면에서의 언어장애 특성. 대한치매학회지, 12, 33-40.

태진이, 이창환, 이윤형(2015). 한국어 시각 단어재인과정에서 음운정보와 표기정보의 역할. 인지과학, 26, 1-26. 